\title{
MODEL STRATEGI KEBIJAKSANAAN POROS MARITIM PEMBANGUNAN GLOBAL HUB BANDAR KAYANGAN KABUPATEN LOMBOK UTARA
}

\author{
Joko Susilo Raharjo ${ }^{1}$, Ermaya Suradinata ${ }^{2}$, Sampara Lukman $^{3}$, Lalu Wildan 4 \\ ${ }^{1,2,3,4}$ Institut Pemerintahan Dalam Negeri (IPDN) \\ Email: joko68susilo@gmail.com
}

\begin{abstract}
Abstrak
Dalam menuju Poros Maritim Dunia dan memanfaatkan potensi ALKI II sebagai Alur Laut Kepulauan Indonesia dapat dimaksimalkan dengan melakukan pembangunan berbasis kemaritiman. Indonesia menuju poros maritim dunia yang dapat diwujudkan melalui rencana pembangunan pelabuhan global Hub Internasional di Bandar Kayangan Lombok Utara Provinsi Nusa Tenggara Barat. Penelitian ini bertujuan untuk menemukan pengembangan model baru, dengan menggunakan desain penelitian kualitatif dengan tipe penelitian deskriptif. Analisis yang digunakan dalam penelitian ini adalah analisis implementasi kebijaksanaan publik model Grindle (1980) dan dilanjutkan dengan analisis strategi ASOCA. Kebijaksanaan pembangunan global Hub Bandar Kayangan belum maksimal. Oleh karena itu diperlukan strategi untuk pemecahan masalah dalam pengambilan keputusan. Dari hasil analisis implementasi kebijaksanaan publik berdasarkan temuan empirik analisis strategi ASOCA maka, diperoleh konsep baru strategi model 7 P JSRW, yaitu: Peran pemerintah (proses Pendelegasian), Peraturan zonasi, Peran media dalam membuat opini public, Pemanfaatan tenaga kerja lokal, Peran perguruan tinggi dalam mencetak tenaga ahli, Pelaku bisnis (menarik investor), dan Pemberlakuan hukum yang adil.
\end{abstract}

Kata Kunci: Model, Strategi Kebijakan, Poros Maritim, Global Hub.

\begin{abstract}
In heading towards the World Maritime Axis and utilizing the potential of ALKI II as the Indonesian Archipelago Sea Channel, it can be maximized by conducting maritime-based development. Indonesia is heading towards the world's maritime axis which can be realized through the plan to develop an International Port global hub in Bandar Kayangan, North Lombok, West Nusa Tenggara Province. This study aims to find the development of new models, using qualitative research designs with descriptive research type. The analysis used in this study is an analysis of the implementation of Grindle's (1980) model of public policy and continued with the analysis of the ASOCA strategy. The Bandar Kayangan Hub global development policy has not been maximized. Therefore we need a strategy for solving problems in decision making. From the results of the analysis of the implementation of public policy based on empirical findings of ASOCA strategy analysis, a new concept of JSRW 7P model is obtained, namely: The role of government (Delegation process), Zoning regulations, The role of the media in making public opinion, Utilization of local workforce, The role of universities in printing experts, business actors (attracting investors), and the application of fair law.
\end{abstract}

Keywords: Model, Policy Strategy, Maritime Axis, Global Hub. 


\section{ARTIKEL}

\section{A. PENDAHULUAN}

Sebagai negara kepulauan terbesar di dunia, Indonesia memiliki tiga perempat wilayahnya dalam bentuk laut dengan kekayaan sumber daya alam yang melimpah dan jasa lingkungan (jasa lingkungan) yang sangat besar, ekonomi kelautan merupakan keunggulan komparatif. yang dapat diubah menjadi keunggulan kompetitif dan sumber pertumbuhan ekonomi baru bagi Indonesia. Arah kebijakan di sektor pelabuhan menekankan pada pengaturan manajemen pelabuhan yang baik dengan mengacu pada pembangunan daerah dan peningkatan ekonomi. Hal ini juga dipikirkan oleh Pemerintah Provinsi Nusa Tenggara Barat pada khususnya, sebagai salah satu upaya pemerintah daerah dalam meningkatkan pertumbuhan ekonomi dan pembangunan.

Provinsi Nusa Tenggara Barat harus dapat membaca peluang ini dengan baik, karena memiliki lokasi yang sangat strategis yang terletak langsung di perairan laut di barat dan timur, yang memiliki potensi kekayaan laut yang besar di dalamnya yang dapat menjadi sumber pendapatan untuk populasi dari sektor perikanan, wisata bahari dan juga posisi strategisnya di ALKI II dalam jalur pelayaran dan perdagangan nasional dan internasional. Untuk alasan ini, Provinsi Nusa Tenggara Barat sangat tergantung pada transportasi laut, pengoperasian pelabuhan secara efektif adalah cita-cita Provinsi Nusa Tenggara Barat, dalam rangka mewujudkan visi pembangunan di bidang pelabuhan yang ditetapkan oleh Pemerintah.

Melihat potensi ini, Pemerintah Provinsi Nusa Tenggara Barat kemudian mengembangkan Global Port Hub Global Development Plan yang akan dibangun di Kabupaten Lombok Utara. Pengembangan Pelabuhan Global kota pelabuhan surga juga dapat memiliki efek positif lainnya, yang dapat meningkatkan pertumbuhan ekonomi di provinsi Nusa Tenggara Barat dan penerimaan Pendapatan Asli Daerah (PAD) akan meningkat secara signifikan jika Pelabuhan Bandar Kayangan dibangun, karena pemerintah akan mendapatkan pemasukan dan kegiatan dari pelabuhan, selain itu, pelabuhan akan membuat perekonomian di sekitar kawasan menjadi terentang. Pertumbuhan ekonomi dan peningkatan PAD akan membuat pemerintah provinsi Nusa Tenggara Barat memiliki lebih banyak dana untuk membiayai pemerintah dan menyediakan dana untuk kesejahteraan penduduk seperti kesehatan, pendidikan, dan lainnya.

Melihat dari uraian di atas, rencana pengembangan pelabuhan ini adalah rencana pengembangan pelabuhan terbesar di Indonesia yang akan memberikan dampak positif juga bagi Negara Indonesia nantinya. Potensi besar ini harus dimanfaatkan oleh pemerintah untuk 


\section{ARTIKEL}

meningkatkan pertumbuhan ekonomi dan dapat digunakan untuk rencana induk pelabuhan Dengan dikeluarkannya Peraturan Pemerintah No. 13 tahun 2017 tentang (RTRWP) Pengembangan Hub Global Bandar Kayangan yang akan dapat meningkatkan kegiatan industri perdagangan, sinergi antara perencanaan, pemanfaatan dan kontrol spasial potensi daerah berbasis lingkungan belum berjalan, harus segera dilaksanakan untuk meningkatkan pendapatan negara dan daerah. Desain global hub ban surga akan seperti kota modern Dubai di Indonesia yang dapat merapat kapal sepanjang 500 meter dengan kedalaman hingga 35 meter dengan kehadiran kilang minyak di kota surga akan mampu menyedot 200 hingga 300 ribu pekerja. Masalah lain adalah, mempertimbangkan penggunaan potensi di bidang kelautan sekarang menjadi prioritas utama dan harus bersinergi dengan bidang lain dalam pembangunan nasional. Karena besarnya jumlah sumber daya laut yang harus dimanfaatkan Indonesia secara optimal dan berkelanjutan. Namun, pada kenyataannya di lapangan, pembangunan kelautan Indonesia juga belum dilakukan secara terintegrasi, di mana ia masih bersifat sektoral, naratif, dan terfragmentasi, yang sering mengakibatkan tumpang tindih dalam implementasi dan pengelolaannya. Hal ini dapat diamati dengan tidak adanya grand design untuk pengembangan sektor maritim Indonesia yang disepakati oleh semua pemangku kepentingan yang terlibat. Oleh karena itu, untuk mengoptimalkan sumber daya laut yang mereka miliki dalam rangka mempercepat pembangunan nasional sehingga Indonesia yang mandiri, maju, adil dan makmur terwujud, diperlukan Kebijakan Kelautan yang kuat dan tepat.

Banyak peneliti melakukan penelitian terutama dalam judul strategi kebijaksanaan (Yusuf, dkk., 2005; Suherman \& Daud, 2008; Supriatna, dkk., 2018; Jati, 2012; Suryadi, 2019), tetapi penelitian akan dilakukan oleh para peneliti, di khususnya, Analisis Kebijakan Kapak Maritim dalam Rencana Pembangunan Global Hub Bandar Kayangan belum dilakukan oleh peneliti lain. Di atas adalah dasar bagi para peneliti melakukan penelitian dengan alasan pertama belum ada dilakukan oleh peneliti lain, terutama penelitian model strategi kebijaksanaan poros maritim pembangunan Global Hub Bandar Kayangan Kabupaten Lombok Utara

\section{B. METODE PENELITIAN}

Penelitian ini menggunakan desain penelitian kualitatif dengan metode deskriptif (Auerbach \& Silverstein, 2003; Creswell, 2013; Wolcott, 2009; Denzin \& Lincoln, 2005). Teknik pengumpulan data yang digunakan dalam penelitian ini meliputi observasi, wawancara 


\section{ARTIKEL}

mendalam, dan studi dokumentasi. Analisis data dilakukan dengan model Milles dan Hubberman (1994) yang terdiri dari reduksi data, penyajian data, dan penarikan kesimpulan serta verifikasi.

\section{HASIL DAN PEMBAHASAN}

\section{a. Model Strategi Kebijaksanaan (ASOCA)}

Model merupakan usaha menyederhanakan kompleksitas realitas yang diteliti agar mudah dimengerti dan menjadi petunjuk dalam pengambilan kebijakan. Proses pembangunan model dalam penelitian ini mempertimbangkan kondisi dan situasi lokasi penelitian yang sangat dipengaruhi oleh berbagai hal seperti yang tergambarkan pada pembahasan sebelumnya. Proses penyusunan model dalam artikel ini diperoleh dari olahan data penelitian yang didasari pada hasil pengolahan data dengan menggunakan klasifikasi unsur-unsur analisis strategi ASOCA.

Analisis strategi ASOCA dilakukan, dengan melihat dua dimensi utama yaitu; Analisis lingkungan internal dengan faktor yang mempengaruhi adalah; (1) faktor kekuatan (strength), (2) faktor kemampuan (ability), (3) faktor kecerdasan (agility). Dan analisis dimensi lingkungan eksternal, dengan faktor yang mempengaruhi adalah; (1) faktor peluang (Opportunities), (2) faktor budaya (Culture). Konsep baru yang diperoleh untuk mendapatkan model baru dari pembahasan Pengolahan isu strategis yang dihasilkan dari ASOCA menjadi 6 (enam) strategi, dapat diurut berdasarkan bobot melalui kecerdasan dalam rangka mengembangkan sektor dan komoditi unggulan sesuai dengan kondisi budaya masyarakat setempat, kecerdasan untuk mengembangkan budaya saling berkoordinasi dan berkomunikasi secara terpadu dan harmonis, dan kecerdasan untuk meningkatkan budaya kerja aparatur pelaksana kebijaksanaan. Berdasarkan analisis tersebut dapat dijadikan sebagai konsep baru dalam penelitian ini.

Berdasarkan pembobotan tersebut diatas dapat diurutkan sebagai berikut:

a. Artinya, dengan strategi dan langkah-langkah dalam kebijaksanaan perencanaan pembangunan Global Hub Bandar Kayangan dalam upaya untuk mempercepat proses pembangunan, dengan penggabungan faktor kekuatan dengan memanfaatkan faktor peluang, terlihat bahwa strategi pemerintah Provinsi Nusa Tenggara Barat dalam mengatasi keterlambatan pembangunan daerah adalah tepat. Dari analisis SO, menunjukan bahwa peranan kekuatan Bappeda dalam menyusun perencanaan pembangunan untuk memanfaatkan peluang yang ada. Dengan berperannya semua aktor, memiliki kesempatan yang sama dalam melakukan sinkronisasi dokumen perencanaan, 


\section{ARTIKEL}

kelembagaan dan potensi unggulan, untuk mendukung berlangsungnya pembangunan memperhatikan kondisi Ekonomi, Sosial-Budaya, Politik dan geografis di nusa tengara barat

b. Artinya dengan strategi dan langkah-langkah untuk kebijaksanaan perencanaan pembangunan Global Hub Bandar Kayangan dibutuhkan penggabungan antara faktor kemampuan dengan memanfaatkan faktor puluang. Dengan penggabungan faktor kemampuan dengan memanfaatkan faktor peluang (AbO). Membuat peraturan zonasi yang memuat ketentuan kegiatan dan penggunaan lahan, ketentuan intensias pemanfaatan ruang, ketentukan tata masa bangunan, ketentuan prasarana dan sarana minimum, ketentuan tambahan, ketentuan khusus, standar teknis,Membuat rencana induk kawasan pelabuhan (detail masterplan) Membuat rencana detail engineering design (DED) penjelas pelaksanaan keteknisan kawasan, sebagai bahan dalam penyusunan awal studi kelayakan (feasibility study) Pembangunan Global Hub Bandar Kayangan, untuk menilai apakah rencana kawasan industri tersebut layak dan memberikan keuntungan yang mamadai dari segi finansial, Membuat studi AMDAL (analisis mengenai dampak lingkungan sehingga tercipta efektivitas perencanaan pembangunan di Nusa Tenggara Barat.

c. Dengan penggabungan faktor kecerdasan dengan memanfaatkan faktor peluang (AgO). Menciptakan peluang-peluang investasi yang prospektif dan meningkatkan promosi investasi guna memperkenalkan, memberikan pemahaman umum, menanamkan citra (image), serta membujuk dan menarik investor untuk menanamkan modalnya di Pembangunan Global Hub Bandar Kayangan, meningkatkan kesiapan pemerintah Kabupaten Lombok Utara dan Provinsi Nusa Tenggara Barat dalam hal penataan ruang, penyediaan peluang investasi, pengalokasian anggaran, maupun kesiapna-kesiapan pendukung lainnya Strategi menyusun keterpaduan perencanaan dan penganggaran, mengelola opini masyarakat, dan pengawasan kepada aparatur pelaksana kebijaksanaan diperlukan kecerdasan dalam pemanfaatan insentif regulasi, Strategi menyusun keterpaduan perencanaan dan penganggaran, mengelola opini masyarakat, dan pengawasan kepada aparatur pelaksana kebijaksanaan diperlukan kecerdasan dalam pemanfaatan insentif infrastruktur transportasi berupa Alur Laut Kawasan Indonesia (ALKI) II dan Program Poros Maritim Dunia. pelaksana kebijaksanaan diperlukan 


\section{ARTIKEL}

kecerdasan dalam pengelolaan peluang peningkatan kesejahteraan ekonomi. Prioritas strategi kebijaksanaan dalam perencanaan pembangunan Global Hub Bandar kayangan.

d. Dengan penggabungan faktor kekuatan dengan memanfaatkan faktor budaya (SC). Pemanfaatan tenaga kerja setempat atau menempatkan masyarakat setempat sebagai bagian integral dari keberadaan kegiatan Pembangunan Global Hub Bandar Kayangan, memberi dukungan penuh kepada masyarakat dengan memberikan modal dalam mendorong usaha-usaha kecil dan menengah dan industri rumahan, Kekuatan untuk mengembangkan sektor dan komoditi unggulan sesuai dengan kondisi budaya masyarakat lokal, mengembangkan budaya saling berkoordinasi dan berkomunikasi secara terpadu dan harmonis. melalaui koordinasi dan komunikasi yang partisipatif untuk menjaga kearifan lokal yang dimiliki sebagai kekuatan dalam mengimplementasikan kebijaksanaan dalam perencanaan pembangunan Global Hub Bandar Kayangan Nusa Tenggara Barat.

e. Dengan penggabungan faktor kemampuan dengan memanfaatkan faktor budaya (AbC). Membangun kerjasama antara Dinas dalam hal ini Balai Pendidikan dan Latihan dengan dunia industri khususnya industri yang ada di Lokasi pembangunan Global Hub Bandar Kayangan,upaya ini ditujukan untuk mengidentifikasi kompetensi yang diperlukan dunia industri, Membangun kewirausahaan dan semangat berwirausaha, dengan memberikan kesempatan untuk bekerja sama dengan industri sekitar Pembangunan Global Hub Bandar Kayangan,mampu mempengaruhi dinamika lingkungan ekonomi, sosial dan politik dalam rangka mengembangkan sektor dan komoditi unggulan sesuai dinamika lingkungan ekonomi, sosial dan politik untuk, mengembangkan budaya saling berkoordinasi dan berkomunikasi secara terpadu dan harmonis dengan kondisi budaya masyarakat setempat, yang dijabarkan dalam program dan kegiatan untuk mendukung lingkungan ekonomi, sosial dan politik berbasis kearifan lokal.

f. Dengan penggabungan faktor kecerdasan dengan memanfaatkan faktor budaya (AgC), Bersama-sama dengan dunia industri menyelenggarakan pelatihan yang bersifat teknis maupun non teknis seperti peningkatan kecakapan hidup (life skill), Mengusahakan peningkatan kemampuan dan kualitas kerja penduduk melalui pengembangan pendidikan formal dalam berbagai tingkatan atau melalui program-program latihan keterampilan yang secara spesifik diarahkan kepada kebutuhan tenga kerja trampil bagi industri 
ARTIKEL

tertentu yang ada Global Hub Bandar Kayangan, masyarakat yang berada di sektor juga dibimbing sehingga akan selalu seimbang dan selaras dengan setiap perubahan teknologi agro yang berkembang di Lokasi Pembangunan Global Hub Bandar Kayangan memaksimalkan Kapabilitas aparatur pemerintah daerah dalam mengelola opini masyarakat yang berkaitan dengan sumber daya alam kemaritiman, sehingga dapat menjaga stabilitas internal pemerintah daerah dalam melaksanakan implementasi kebijaksanaan perencanaan pembangunan daerah melalui investasi bidang kemaritiman.

Modifikasi model di atas memiliki hubungan yang sangat erat dan mendukung proses kebijaksanan, di mana dimensi standar dan tujuan serta dimensi sumber daya menjadi input pada strategi implementasi kebijaksanaan sebagai informasi yang digunakan untuk mengkaitkan dengan desain pola komunikasi. Dimensi komunikasi antar organisasi, serta sebagai petunjuk arah dalam membentuk karakter dimensi desain organisasai implementator. Hubungan strategi implementasi dengan kondisi sosial, ekonomi dan politik serta ada tambahan indikator wilayah (geografik). Hal ini menunjukan pemahaman fenomena perubahan yang terjadi di lokus implementasi.

Uraian tersebut memperlihatkan strategi yang dianggap cocok untuk menjadi dasar dari implementasi pembangunan Global Hub Bandar Kayangan adalah opportuinites dan agility, yaitu menggunakan kecerdasan untuk memanfaatkan peluang yang ada. Peluang ALKI II menjadi dasar terhadap diperlukannya perubahan untuk dapat memaksimalkan potensi tersebut, ditunjang dengan adanya kebutuhan terhadap moda transportasi efektif yang mampu mendistribusikan berbagai komoditi unggulan ke berbagai daerah di Indonesia maupun mancanegara.

Peluang tersebut diharapkan mampu meningkatkan kondisi ekonomi yang ada di Provinsi Nusa Tenggara Barat, baik dalam konteks perdagangan, distribusi barang unggulan seperti pertanian, barang tambang, maupun pariwisata. Kondisi kemampuan (strength) yang ada tidak mampu menjawab peluang yang dimiliki oleh Provinsi Nusa Tenggara Barat. Oleh sebab itu, agility diperlukan untuk menjawab tantangan tersebut dengan dalam membangun lokasi Global Hub Bandar Kayangan sebagai destinasi yang dianggap menjanjikan sebagai moda transportasi utama dalam kegiatan ekonomi.

Namun pada implementasinya, diperlukan strategi agility lain untuk dapat memaksimalkan pembangunan Global Hub Bandar Kayangan yang masih mengalami berbagai 


\section{ARTIKEL}

hambatan. Berdasarkan hasil analisis ASOCA, peneliti membuat sebuah model Tujuh P (JSRW), yang didalamnya menjelaskan strategi dengan melakukan berbagai kebijaksanaan inkremental yang terkait dalam proses pembangunan Global Hub Bandar Kayangan.

\section{Model Strategi Kebijaksanaan 7P (JSRW)}

Kebijaksanaan $\mathrm{P}$ pertama ialah, Peran Pemerintah pusat dalam pendelegasian kewenangan (delegation or institutional pluralism), yaitu pelimpahan wewenang untuk tugas tertentu kepada organisasi yang berada di luar struktur birokrasi reguler yang dikontrol secara tidak langsung oleh Pemerintah Pusat. Pendelegasian wewenang ini biasanya diatur dengan ketentuan perundang-undangan. Pihak yang menerima wewenang mempunyai keleluasaan (discretion) dalam penyelenggaraan pendelegasian tersebut, walaupun wewenang terakhir tetap pada pihak pemberi wewenang (sovereign authority). Dalam Pembangunan Global Hub dan industri Pemerintah Kabupaten Lombok Utara bekerja sama dengan pihak Pemerintah Provinsi Nusa Tenggara Barat melakukan upaya mengajukan permohonan surat pemerintah pusat, agar pemerintah provinsi diberikan kewenangan membebaskan status ahli fungsi kawasan yang akan dipakai selama kawasan tersebut digunakan untuk infrastruktur pembangunan. Hal tersebut perlu dilakukan segera agar langkahlangkah selanjutnya dapat berjalan tahapan pelaksanaan pembangunan Global Hub Bandar Kayangan. Setelah status kawasan beralih fungsi menjadi kawasan industri.

P kedua, peraturan zonasi. Peraturan zonasi berfungsi sebagai instrumen pengendalian pemanfaatan ruang dan Rencana Rinci Kawasan Strategis pembangunan Global Hub Bandar Kayangan dan Kawasan Industri Terpadu Bandar Kayangan sebagai panduan teknis untuk pengembangan tampak pemanfaatan lahan karena mencakup penggunaan lahan, intensitas pembangunan, tata massa bangunan, prasarana minimum dan standar perencanaan. Hadirnya pembangunan Global Hub Bandar Kayangan diharapkan agar dapat menunjang kebutuhan hidup dan kepentingan masyarakat di wilayah Provinsi Nusa Tenggara Barat yang rencananya akan dibangun bisa menjawab masalah-masalah tersebut dengan melihat peluang yang ada karena letak posisinya yang sangat strategis terletak pada jalur ALKI II dan jalur perdagangan.

P ketiga, terkait Peran Media dalam hubungan dengan masyarakat melalui strategi pembangunan opini publik. Opini publik merupakan sebuah ekspresi dari semua anggota kelompok yang memberikan perhatian atau tanggapan terhadap sebuah isu melalui beragam cara, 
dan dapat diiakukan dengan menghantarkan sugesti melalui penggunaan bahasa yang di dorong dengan faktor ekonomi sebagai faktor utama, Hal tersebut dapat dilakukan dengan berbagai sosialisasi maupun komunikasi melalui media baik cetak maupun elektronik akan pentingnya pembangunan Global Hub Bandar Kayangan terutama secara ekonomi yang dapat meningkatkan mutu hidup dan kesejahteraan masyarakat sekitarnya. Melalui pembentukan opini publik, diharapkan masyarakat dapat mendukung penuh proses implementasi pembangunan Global Hub Bandar Kayangan, Strategi pembentukan opini publik diharapkan juga dapat mendorong political will dari berbagai lapisan atau tingkatan institusi. Terciptanya political will akan memudahkan relasi, koordinasi, dan feed beck bagi proses kebijaksanaan Pembangunan Global Hub Bandar Kayangan. Hal tersebut karena dapat beriringan dengan pembentukan pola transaksi yang sinergis antar institusi.

Kondisi tersebut sejalan dengan model Smith bahwa institusi pengimplementasi berperan penting dalam proses kebijaksanaan terutama bagi Pemerintah pusat, Provinsi, maupun Daerah, sehingga political will akan mampu menjadi dasar terbentuknya komunikasi yang solid atau kuat dan sinergis antar institusi. Komunikasi yang solid dan sinergis tersebut utamanya Pemerintah Provinsi Nusa Tenggara Barat bersama-sama dengan Pemerintah Kabupaten Lombok Utara dalam melaksanakan rencana pembangunan Global Hub Bandar Kayangan tersebut demi mencapai tujuan yang diinginkan. Lebih jauh, hal tersebut akan memberikan pengaruh penting terhadap proses implementasi kebijaksanaan pembangunan Global Hub Bandar Kayangan berjalan optimal.

P keempat, Pekerja terutama pada pemanfaatan tenaga kerja setempat atau penempatkan masyarakat setempat sebagai bagian integral dari keberadaan kegiatan Pembangunan Global Hub Bandar Kayangan dan Industri Terpadu. Kegiatan tersebut memberikan dukung penuh kepada masyarakat dengan memberikan modal dalam mendorong usaha-usaha kecil dan menengah dan industri rumahan. Dukungan tersebut seperti membangunn kerjasama antar Dinas dalam hal ini Balai Pendidikan dan Latihan dengan dunia industri khsususnya industri yang ada sekitar lokasi pembangunan dan masyarakat Nusa Tenggara Barat khususnya, adanya pelatihan tersebut mempermudah dan meningkatkan kapasitas kompetensi yang diperlukan dunia industri. Tidak hanya demikian, perlu juga membangun suasana kewirausahaan dan semangat berwirausaha, dengan memberikan kesempatan untuk bekerjasama dengan Industri Terpadu pembangunan Global Hub Bandar Kayangan. Bentuk kerjasama tersebut seperti bersama-sama dengan dunia 
industri menyelenggarakan pelatihan yang bersifat teknis maupun non teknis seperti peningkatan kecakapan hidup (life skill). Seiring dengan hal tersebut, adapun upaya peningkatan kemampuan dan kualitas kerja penduduk melalui pengembangan pendidikan formal dalam berbagai tingkatan atau melalui program-program latihan keterampilan. Program latihan tersebut secara spesifik terutama diarahkan kepada kebutuhan tenaga kerja terampil bagi industri yang ada di Pembangunan Global Hub Bandar Kayangan. Pada program pelatihan tersebut juga meliputi bagaimana masyarakat yang berada di sektor agraris juga dapat dibimbing sehingga, akan selalu seimbang dan selaras dengan setiap perubahan teknologi agro yang berkembang di sekitar lokasi Industri Terpadu Bandar Kayangan. Strategi tersebut tersebut akan memengaruhi dalam konteks model Smith yang telah dipaparkan sebelumnya terutama pada faktor lingkungan. Ketika faktor lingkungan mencapai posisi optimal yaitu masyarakat mendukung penuh proses kebijaksanaan pembangunan Global Hub Bandar Kayangan, dan memiliki keterampilan dan kemampuan dalam memenuhi kebijaksanaan pembangunan Global Hub Bandar Kayangan, akan secara langsung berpengaruh pada niat dan tujuan awal dari kebijaksanaan ideal yang ingin dicapai. Berdasarkan kendala lain yang dibadapi pada pembangunan Global Hub Bandar Kayangan terutama dalam hal SDM yang kurang memadai. Kurang memadainya SDM yang ada, maka diperlukan peningkatan maupun penyerapan SDM dari berbagai keahlian yang sesuai sebagai strategi.

P yang kelima: Perguruan Tinggi. Hal tersebut salah satunya dapat dilakukan dengan melakukan kerjasama dengan berbagai universitas terkait proses pembangunan Global Hub Bandar Kayangan. Kerjasama tersebut dapat membantu dalam proses kajian-kajian, maupun hingga pada proses pengembangan dan pembangunan Global Hub Bandar Kayangan. Selain melakukan kerjasama dengan universitas, perlu juga melakukan rekrutmen terhadap ahli-ahli yang dianggap dapat membantu proses pembangunan Global Hub Bandar Kayangan baik pada teknis maupun substansial. Selain itu, membuat rencana induk (detail-masterplan) kawasan Pembangunan Global Hub Bandar Kayangan menjadi strategi.

P keenam. Pelaku Bisnis Menarik Investor Rencana tersebut termasuk melingkupi detail engineering desaian (DED) penjelas pelaksanaan teknis kawasan, sebagai bahan dalam penyusunan awal studi kelayakan (feasibility study). Feasibility study dapat dilaksanakan seperti melakukan studi AMDAL (analisis mengenai dampak lingkungan). Sementara itu, detailmasterplan juga harus memiliki unsur sebagai dasar dari upaya untuk meyakinkan adanya peluang peluang investasi maupun prospektif dan meningkatkan promosi investasi guna 


\section{ARTIKEL}

memperkenalkan, memberikan pemahaman umum, menanamkan citra (image), serta membujuk dan menarik minat investor untuk menanamkan modalnya di Pembangunan Global Hub Bandar Kayangan dan Industri Terpadu. Selain itu, perlu adanya pembelajaran atau adaptasi kebijaksanaan yang sejenis dari daerahdaerah lain, terutama untuk memberikan sudut pandang yang lebih luas terhadap penerapan atau kebijaksanaan pembangunan Global Hub Bandar Kayangan. Bekerjasama dengan pihak swasta dalam kebijaksanaan pembangunan Global Hub Bandar Kayangan Sejalan dengan model Smith di mana pola transaksi dan tekanan tidak hanya berjalan pada antar institusi maupun masyarakat, tetapi dengan adanya dorongan pihak swasta maupun investor akan memberikan dampak ke berbagai elemen impelementasi pembangunan Global Hub Bandar Kayangan Terkait dengan kerjasama dengan swasta, sejalan dengan Considine dan Giguere, (2008:1) tentang di mana 'Kemitraan' atau partnership adalah penggabungan sebuah fitur standar kebijakan dan pengambilan keputusan pada dalam berbagai tingkatan. Sebagai contoh misalnya pada aspek dunia industrilisasi, bukanlah hal yang tidak biasa saat kabinet mendiskusikan terlebih dahulu dalam mengeluarkan program terbaru untuk didengarkan kepada pemimpin politik untuk meningkatkan kemungkinan dari keterlibatan sebuah jaringan dari area basis kerjasama dalam proses implementasi. Seperti halnya pada tingkat Pemerintahan lokal, hal tersebut berkaitan juga dalam aspek ekonomi atau pengembangan sosial (seperti Pegawai Negeri Sipil, ataupun keanggotaan kamar perdagangan atau dari perwakilan Non Government Organization (NGO) lebih mungkin daripada tidak bertemu satu sama lain untuk membahas masalahmasalah lokal pada pertemuan kemitraankemitraan diberdayakan secara lokal.

Considine dan Giguere lebih lanjut, menjelaskan tujuan utama dari kemitraan adalah untuk mengambil pendekatan yang terintegrasi pada isu-isu spesifik, atau untuk memperhitungkan berbagai dimensi masalah tertentu. Hal tersebut untuk memberikan saran dan mempromosikan solusi yang memungkinkan menjadi hasil terbaik secara keseluruhan. Solusi tersebut mungkin memiliki implikasi untuk pelaksanaan program publik lainnya, dan proyekproyek sektor swasta atau sukarela, yang mungkin dapat merekomendasikan, mengalihkan, menunda atau reorientasi kegiatan. Hal tersebut menjelaskan bahwa kemitraan perlu dibangun dalam pembangunan Global Hub Bandar Kayangan. Kemitraan dapat menjadi dorongan pihak swasta yang akan memberikan dampak seperti, pembangunan infrastruktur, peningkatan investasi, penyerapan tenaga kerja termasuk juga meningkatkan kompetisi yang sehat pada 


\section{ARTIKEL}

perdagangan dalam negeri maupun luar negeri. Sinergitas tersebut perlu dibangun dengan adanya keyakinan bahwa pembangunan Global Hub Bandar Kayangan memiliki nilai ekonomi yang tinggi dengan adanya jalur perdagangan internasional, pemanfaatan sumber daya alam, maupun sektor pariwisata, dan secara langsung akan berdampak pada pembangunan ekonomi daerah dan peningkatan kesejahteraan masyarakat.

P ketujuh pemberlakuan hukum yang adil,dimana ketegasan dalam menjalaankaan proses pembangunan Global Hub Bandar Kayangan mengacu kepada peraturan Perundang-undangan, Pancasila Sila Kelima Keadilan Sosial Bagi seluruh Masyarakat Indonesia dan dibuat aturan yang mengikat untuk ditaati bersama antar pemerintah pelaku usaha masyarakat yang berhubungan dengan pembangunan Global Hub Bandar Kayangan Lombok Utara Provinsi Nusa Tenggara Barat. Penekanan pada proses perancangan kebijaksanaan tujuh $\mathrm{P}$ dilihat dari sisi yang sejalan dengan Considine dan Giguere, (2008:3-4) di mana menunjukkan pada sikap menahan diri dari menggunakan beberapa program dalam keadaan tertentu. Sebagai contoh, logis jika kemitraan mengusulkan pengurangan sejauh mana layanan ketenagakerjaan menghubungkan kategori tertentu dari pencari kerja untuk lowongan pekerjaan berketerampilan rendah, hal tersebut menunjukkan bahwa sekaligus mempromosikan investasi dalam segi pendidikan lebih lanjut mereka sebagai gantinya. Hal tersebut akan menghasilkan respon yang optimal untuk situasi saat di mana rencana investasi diharapkan membawa pekerjaan dengan relatif baik gaji dan prospek karir, yang kategori pekerja yang bersangkutan akan cocok diberikan pelatihan lebih lanjut. Dengan tidak adanya jenis peningkatan skill, pekerja mungkin perlu menarik dari tempat lain, terutama dalam kasus pasar tenaga kerja yang ketat. Sementara itu lowongan pekerjaan berketerampilan rendah tersedia dalam proses mungkin merupakan kesempatan yang berguna untuk memasukkan kelompok sulit dijangkau lainnya ke pasar tenaga kerja.

Berbagai strategi Tujuh P (JSRW) tersebut diharapkan dapat dilaksanakan dan diimplementasikan dengan memperlihatkan urgensi terhadap proses Kebijaksanaan Poros Maritim pembangunan Global Hub Bandar Kayangan, sehingga proses pembangunan dapat berjalan secara optimal dengan adanya hubungan yang sinergis antara instititusi dalam mencapai kebijaksanaan ideal yang diharapkan dengan mengoptimalkan realita yang ada akan mencapapai posisi ideal yang diharapakan. Keterangan (JSRW)

J: Joint (bekerja sama dalam menyelesaikan problem Bandar kayangan) dalam konsep wawancara mendalam antara peneliti dan perancang rencana pembangunan Global Hub Bandar 


\section{ARTIKEL}

Kayangan bahwasanya masyarakat yang terkena dampak dari pembangunan tersebut tanahnya tetap akan menjadi miliknya walaupun sudah dibayar oleh inisiator Global Hub, ini merupakan konsep baru yang betul betul demi kesejahteraan masyarakat dan inilah yang benar menurut peneliti jadi sampai anak cucu masih dapat menikmati dampak dari pembangunan ini. (P 6)

S: Serious (serius dalam penangananya baik pemerintah tingkat pusat maupun daerah) karena untuk mengembalikan kejayaan bangsa Indonesia harus memiliki pelabuhan internasional yang sangat tepat adalah Bandar Kayangan Lombok Utara jadi harus sinergi, proses perizinan tidak berbelit-belit berikan kewenangan gubernur karena gubernur adalah kepanjangan dari pemerintah pusat (P 1 dan P2).

R: Remarkable (menuju kemajuan yang luar biasa) hasil karya yang hebat perencanaan pembangunan pelabuhan internasional Global Hub Bandar Kayangan adalah rencana yang luar biasa karena dengan akan terlaksananya pembangunan tersebut merupakan suatu kebanggaan yang akan membuktikan bahwasanya Indonesia terutama Provinsi Nusa Tenggara Barat khususnya Kabupaten Lomok Utara dapat memiliki pelabuhan Internasional yang akan disinggahi kapal kapal besar yang melalui ALKI II, penyerapan tenaga kerja yang banyak sehingga dapat mengurangi pengangguran serta kita tidak tergantung dengan Negara tetangga dalam proses eksport dan import dalam memasarkan hasil hasil pruduksi lokal asli bangsa Indonesia baik sektor perdagangan, hasil bumi, maupun pruduk pruduk lokal lainnya (P3 dan P5).

W: Waterfront (tepi laut, bagian kota yang berbatasan dengan air, daerah pelabuhan) waterfront activites kegiatan kegiatan di pelabuhan yang akan menjadikan kota baru dalam proses kegiatan perdagangan, perindustrian, penataan pemukiman, galangan kapal, Masyarakat yang berada di sektar juga dibimbing sehingga akan selalu seimbang dan selaras dengan setiap perubahan teknologi agro yang berkembang di Lokasi Pembangunan Global Hub Bandar Kayangan. Bersama-sama dengan dunia industri menyelenggarakan pelatihan yang bersifat teknis maupun non teknis seperti peningkatan kecakapan hidup (life skill). Mengusahakan peningkatan kemampuan dan kualitas kerja penduduk melalui pengembangan pendidikan formal dalam berbagai tingkatan atau melalui program-program latihan keterampilan yang secara spesifik diarahkan kepada kebutuhan tenga kerja trampil bagi industri tertentu yang ada Global Hub Bandar Kayangan. 
ARTIKEL

Masyarakat yang berada di sektar juga dibimbing sehingga akan selalu seimbang dan selaras dengan setiap perubahan teknologi agro yang berkembang di Lokasi Pembangunan Global Hub Bandar Kayangan perkapalan di Bandar Kayangan Provinsi Nusa Tenggara Barat Kabupaten Lombok Utara dalam pemanfaatan Geostrategis memanfaatkan peluang menuju Negara Maritim yang terkemuka di dunia (P 4 dan P7).

Temuan peneliti terkait analisis kebijaksanaan poros maritim dalam Pembangunan Global Hub Bandar Kayangan Provinsi Nusa Tenggara Barat, setelah dikaji menggunkan teori Grindle harus ditambah model temuan 7P (JSRW) sehingga akan terwujud proses pembangunan tersebut, dan dengan terbangunnya Global Hub Bandar Kayangan akan menjadi kunci pembuka dalam menuju Poros Maritim Dunia seperti yang dicita-citakan bangsa Indonesia.

\section{KESIMPULAN}

Berdasarkan hasil analisis yang peneliti lakukan, menghasilkan sebuah model yang dapat mencapai tujuan dari proses kebijaksanaan pembangunan Pelabuhan Global Hub Bandar Kayangan, antara lain adalah sebagai berikut:

1. Pembebasan lahan kawasan hutan lindung, lahan pertanian dan hunian nelayan merupakan langkah awal untuk memasuki tahap selanjutnya seperti, melakukan berbagai pengkajian dan langkah dalam pelaksanaan pembangunan Global Hub Bandar Kayangan.

2. Konsep zonasi yang telah di buat oleh inisiator Bandar kayangan untuk menunjang secara teknis maupun konsep Pembangunan Global Hub Bandar Kayangan yang akan dibangun terutama pemaksimalan kegunaan jalur ALKI II dapat segera diwujudkan tahap awal.

3. Membangun opini publik dengan berbagai sosialisasi dan komunikasi kepada masyarakat, sebagai upaya dalam meningkatkan pemahaman dan dukungan dari masyarakat itu sendiri, termasuk juga dapat mendorong political will dari berbagai lapisan institusi Pemerintah. Strategi tersebut juga dapat memberikan penguatan pada aspek birokrasi maupun koordinasi dengan para stakeholder dan organisasi Pemerintah yang bersinggungan (dari tingkat Kabupaten, Provinsi sampai dengan tingkat pusat) dalam proses kebijaksanaan pembangunan Global Hub Bandar Kayangan terutama untuk mengurus seperti perizinan lokasi. 
4. Pemanfaatan maupun pengembangan tenaga kerja masyarakat setempat diharapkan akan memberikan dukungan penuh kepada pemerintah dalam membantu proses pembangunan Global Hub Bandar Kayangan.

5. Membentuk pola kerjasama dengan universitas dan rekrutmen terhadap ahli-ahli yang dianggap dapat membantu proses pembangunan Global Hub Bandar Kayangan baik pada teknis maupun substansial. Strategi tersebut dapat digunakan sebagai upaya untuk meningkatkan SDM yang kurang memadai.

6. Perencanaan yang sudah dilakukan inisiator Global Hub Bandar Kayangan membuat rencana induk (detail masterplan) kawasan Pembangunan Global Hub Bandar Kayangan rencana tersebut termasuk melingkupi detail engineering desain (DED) penjelas pelaksanaan teknis kawasan, sebagai bahan dalam penyusunan awal studi kelayakan (feasibility study). Feasibility study dapat dilaksanakan seperti melakukan studi AMDAL (analisis mengenai dampak lingkungan). Detail-masterplan juga dapat digunakan sebagai dasar dari upaya untuk meyakinkan adanya peluang-peluang. Peluang tersebut seperti, menanamkan citra (image), serta membujuk dan menarik minat investor untuk menanamkan modalnya di Pembangunan Global Hub Bandar Kayangan.

7. Melakukan kerjasama dengan pihak swasta yang sudah berjalan dengan Inisiator Pembangunan Global Hub Bandar Kayangan dalam kebijaksanaan pembangunan, agar dapat menciptakan peluang investasi yang prospektif dan meningkatkan promosi investasi pembangunan pelabuhan dengan tujuan untuk menggaet sumber daya. Dorongan tersebut dapat memberikan dampak seperti, pembangunan infrastruktur, pendanaan, peningkatan investasi, penyerapan tenaga kerja termasuk juga meningkatkan kompetisi.

8. Menerapkan temuan peneliti model 7P (JSRW) dalam proses percepatan menuju poros maritim dunia dalam Pembangunan Global Hub Bandar Kayangan.

9. Memberikan penambahan anggaran kepada Kementrian Maritim agar lebih fokus dalam kebijaksanaan menuju Poros Maritim Dunia 


\section{DAFTAR PUSTAKA}

Auerbach, C. Y. S., \& Silverstain, L. B. (2003). Qualitative Data. New York: New York University Press.

Creswell, J. W. (1994). Research Design: Qualitative dan Quantitative Approach. California: Sage Publications.

Denzin, N. K., \& Lincoln, Y. S. (2011). The Sage Handbook of Qualitative Research. Sage Publications.

Government Regulation Number 13 of 2017 concerning the Bandar Kayangan Hub Global Development (RTRWP).

Jati, R. (2012). Model Pengelolaan Wilayah Kepesisiran Secara Terpadu Untuk Pengembangan Sistem Pendukung Keputusan Perencanaan Pembangunan Kota Pesisir Berkelanjutan (Kasus Di Kota Semarang dan Kota Cilacap) (Doctoral dissertation, Universitas Gadjah Mada).

Regional Regulation of the Province of West Nusa Tenggara No. 3 of 2010 concerning the West Nusa Tenggara Provincial Spatial Plan (RTRWP).

Suherman, A., \& Dault, A. (2009). Dampak Sosial Ekonomi Pembangunan dan Pengembangan Pelabuhan Perikanan Nusantara (PPN) Pengambengan Jembrana Bali. Jurnal Saintek Perikanan, 4(2), 24-32.

Supriatna, P., Jumiati, I. E., \& Waseh, H. (2018). Analisis Dampak Sosial Ekonomi Kebijakan Pembangunan Pelabuhan PT. Cemindo Gemilang Terhadap Kehidupan Masyarakat Desa Darmasari Kecamatan Bayah Kabupaten Lebakbanten (Doctoral dissertation, Universitas Sultan Ageng Tirtayasa).

Suryadi. (2019). Implementasi Kebijaksanaan Pembangunan Daerah Berbasis Kepulauan di Dukung Poros Maritim di Provinsi Maluku (Doctoral dissertation, IPDN).

Wolcott, H. F. (2009). Writing up Qualitative Research. Thousand Oaks, CA: Sage Publications.

Yusuf, H., Moedikdjo, K., Saeni, M. S., \& Nasution, L. I. (2005). Dampak pembangunan pelabuhan perikanan terhadap penyerapan tenaga kerja dan pendapatan masyarakat (studi kasus di Pelabuhan Perikanan Lempasing Bandar Lampung). Buletin Ekonomi Perikanan, 6(1), 57-64. 